\title{
Exploring the Potential of Andean Crops for the Production of Gluten-Free Muffins
}

\author{
Diego Salazar ${ }^{1,2, *(\mathbb{D})}$, Mirari Arancibia ${ }^{1} \mathbb{D}$, Diego R. Silva ${ }^{1}$, María Elvira López-Caballero ${ }^{3, *(\mathbb{D})}$ \\ and María Pilar Montero ${ }^{3}$ (D) \\ 1 Facultad de Ciencia e Ingeniería en Alimentos, Universidad Técnica de Ambato, Av. Los Chasquis y Rio \\ Payamino, Ambato 180206, Ecuador; marancibias@uta.edu.ec (M.A.); dsilva6949@uta.edu.ec (D.R.S.) \\ 2 Facultad de Veterinaria, Universidad Complutense de Madrid, 28040 Madrid, Spain \\ 3 Instituto de Ciencia y Tecnología de Alimentos y Nutrición (ICTAN-CSIC), Calle José Antonio Novais 10, \\ 28040 Madrid, Spain; mpmontero@ictan.csic.es \\ * Correspondence: dm.salazar@uta.edu.ec (D.S.); elvira.lopez@ictan.csic.es (M.E.L.-C.)
}

check for updates

Citation: Salazar, D.; Arancibia, M.; Silva, D.R.; López-Caballero, M.E.; Montero, M.P. Exploring the Potential of Andean Crops for the Production of Gluten-Free Muffins. Agronomy 2021, 11, 1642. https://doi.org/ 10.3390/agronomy11081642

Academic Editor: Marten Sørensen

Received: 27 July 2021

Accepted: 16 August 2021

Published: 18 August 2021

Publisher's Note: MDPI stays neutral with regard to jurisdictional claims in published maps and institutional affiliations.

Copyright: (c) 2021 by the authors. Licensee MDPI, Basel, Switzerland. This article is an open access article distributed under the terms and conditions of the Creative Commons Attribution (CC BY) license (https:/ / creativecommons.org/licenses/by/ $4.0 /)$.

\begin{abstract}
The aim of this study was to determine the potential of Andean Crop Flours (ACF) to develop muffins suitable for people with celiac disease or gluten intolerance, as these flours do not contain gluten in their composition. The physico-chemical, rheological, microbiological and sensory properties of muffins from different blends of the following ACF were evaluated: camote (Ipomea batatas), oca (Oxalis tuberosa), achira (Canna indica) and mashua (Tropaeolum tuberosum), formulated with sucrose or sucralose. Wheat muffins with sucrose were used for control purposes. The effect of 5-day storage on color, texture and microbiology was also studied. The use of ACF sharply increased the amount of total dietary fiber, while fat and protein contents were slightly lower with respect to the control. Regarding color, formulations with ACF resulted in darker products, showing an important decrease in $\mathrm{L}^{*}$ and $\mathrm{b}^{*}$ values while $\mathrm{a}^{*}$ increased in all ACF formulations. According to their rheological properties, all doughs showed an unstructured and viscous behavior, and the mixture of camote, achira and mashua with sugar was very similar to wheat muffin. On textural parameters, there was an increasing $(p<0.0)$ effect on firmness and chewiness noticeable on day 5 in all samples. The resultant muffins were considered safe products due to low counts of total microorganisms, molds and yeasts and the absence of Enterobacteria and Staphylococcus aureus during storage. Muffins with ACF showed good overall acceptability, especially muffins containing sucralose, which obtained the highest score. This study showed that ACF could be used as an alternative raw material in the preparation of gluten-free muffins with good nutritional quality, thus providing a useful alternative for underused crops.
\end{abstract}

Keywords: Andean agrobiodiversity; camote; oca; mashua; achira; physical properties; dietary fiber; acceptability

\section{Introduction}

In the last decade, the food industry has requested the development of products that may offer alternatives to people with special requirements; for example, people who suffer intolerance or do not assimilate standard components of foods such as gluten [1,2]. For centuries, bakery products, especially bread, have been considered one of the primary foods of society. However, in recent years, bread consumption has decreased considerably due to changes in eating habits (diets, new trends and food fads). Moreover, the growing preference for bread substitutes such as breakfast cereals, and other foods with improved nutritional or functional values [3], has led to a continuous sales growth of foods that differ from the daily-consumed conventional ones [4,5]. Pastry products are essentially heat-dried gels made with flour, eggs and sugar (muffins, cupcakes, cakes, chiffons, among others) and in an infinity of different flavors, colors, sizes and presentations, have been positioned as foods for mass consumption [6,7]. In addition, muffin dough stands out 
for its versatility, adaptability and easy preparation [8,9]. The main component of these products is usually wheat flour. However, about $1 \%$ of the world population suffers from a celiac condition, which is an inflammatory disease of the small intestine triggered by gluten proteins from cereals, particularly wheat, barley and rye $[10,11]$. In this sense, some alternative raw materials rich in nutrients from non-gluten cereals, pseudocereals, legumes, seeds, fruit and vegetables could be used to formulate gluten-free products with proper physical and sensory properties. However, in the case of whole-grain flours and other alternative raw materials, they might have limitations from a technological point of view, since they present changes in the color, aroma, texture, taste and in general in the appearance of resulting products, thus jeopardizing their acceptability. This is why these nutrient-rich raw materials are often used in combination with gluten-free starches and flours [12]. Several studies have focused on replacing gluten in pastry products as muffins with different ingredients such as squash seed dietary fiber [13], a blend of rice, soy and corn starch flours [14], black carrot pomade eggless in a rice-based product [15], cowpea protein isolates in a rice-based product [16], chickpea flour-based batters and muffins [17] and rice flour, potato starch and amaranth flour in different concentrations to formulate gluten-free bread [12]. The design of gluten-free muffins, which are so widely demanded because they are appealing to everyone, is an opportunity to enrich gluten-free foods that sometimes exhibit a poor nutritional profile [18]. However, despite this wide range of mentioned possibilities, there is scarce information about the use of blend flours from Andean crops for the development of gluten-free muffins.

Andean crops have historically been a primary source of food for the indigenous population of countries located throughout the Andes Mountains $[19,20]$. Ecuador has an extensive variety of Andean crops, but most of them have been relegated over time in favor of others which are more profitable or, in turn, due to a lack of knowledge of their nutritional components, functional and physico-chemical properties, and, therefore, of their potential use and applications in the food industry [21,22]. Among the ancestral Andean underutilized crops (in Quechua aboriginal names) are camote (Ipomea Batatas), oca (Oxalis tuberosa), achira (Canna indica) and mashua (Tropaeolum tuberosum). Despite their low consumption, these crops could be of interest because of their nutritional composition (starches, proteins, essential fatty acids), functional properties (for example, as stabilizers) and absence of gluten $[23,24]$. Likewise, anthocyanins, qualified as anticancer or antiprostatic agents, have been found in oca and camote, and anaphrodisiac properties have been attributed to the isothiocyanates in mashua $[23,25]$. Furthermore, a natural sweetening effect is observed in oca and mashua when they are exposed to sunlight (caused by the conversion of starches into sugars), that would allow obtaining sweet products with a reduced load of added sucrose and even replacing it completely [26]. Furthermore, the physico-chemical attributes of achira as a gelling agent and stabilizer were used to develop highly functional products with similar sensorial characteristics to the traditional wheat bakery ones [27].

Therefore, Andean crops could be added to improve processing or to produce specialty and novelty products. These products will often present an increased nutritive value, becoming a good alternative as raw materials in the food industry, mainly in bakery and pastry making, where wheat flour is the most used ingredient because of its excellent bakery capacities.

So, the objective of the present study was to develop gluten-free muffins from formulations of underutilized flour blends of Andean crops as a model cake system. A characterization of the muffins was conducted in terms of physicochemical, sensory properties and microbiological stability, in order to evaluate the behavior of flour blends and their capacities. Muffins with commercial wheat flour were also elaborated for comparison. 


\section{Materials and Methods}

\subsection{Andean Crops Flours (ACF)}

Camote (Ipomea Batatas), oca (Oxalis tuberosa), achira (Canna indica) and mashua (Tropaeolum tuberosum) were purchased in a local market (Ambato, Ecuador). Andean crops were separately washed with water, drained and cut into slices of approximately $2 \mathrm{~mm}$ and dried at $60{ }^{\circ} \mathrm{C}$ for $\sim 24 \mathrm{~h}$ until moisture was constant. Dried slices were then milled in an industrial cereal mill (Inox Equip IE1, Riobamba, Ecuador) to obtain the respective flours. Flours were hermetically packed in polyethylene bags at room temperature until later use. The resulting flours showed the following characteristics: camote flour (C) (moisture 6.2\%; fat $0.37 \%$; protein $4.65 \%$; fiber $11.19 \%$; ashes $3.24 \%$ and carbohydrates $74.35 \%$ ), oca flour (O) (moisture $16.4 \%$; fat $1.06 \%$; protein $1.63 \%$; fiber $5.33 \%$; ashes $3.04 \%$ and carbohydrates $72.54 \%$ ), mashua flour (M) (moisture $18.87 \%$; fat $0.59 \%$; protein $9.12 \%$; fiber $9,6 \%$; ashes $4.94 \%$; and carbohydrates $56,89 \%$ ) and achira flour (A) (moisture $5.94 \%$; fat $0.63 \%$; protein $4.80 \%$; fiber $11.51 \%$; ashes $8.04 \%$ and carbohydrates $69.08 \%$ ). Commercial wheat flour (W) (moisture $12.7 \%$; fat $2.7 \%$; protein $10.2 \%$; fiber $2.7 \%$; ashes $0.65 \%$; and carbohydrates $71.05 \%)$ was used as a control.

\subsection{Batter Formulation and Baking Procedure}

Four gluten-free muffin formulations were prepared with 35\% of Andean crop flours (ACF) and $65 \%$ of a mix of sunflower oil, skim yogurt, eggs, sweetener (powdered sugar or commercial sucralose) and baking powder (1\%), as shown in Table 1 . The control muffins (C) were elaborated with wheat flour (it was used as a reference because this kind of muffin is the most widely known and consumed). The ingredients were individually weighed using an electronic scale (Model V-350, ACCULAB, NY, USA).

Table 1. Muffin formulations prepared with Andean crops flours (ACF).

\begin{tabular}{cccccc}
\hline Ingredients (\%) & Control & CAMa & OAMa & CAMe & OAMe \\
\hline Wheat & 33.02 & - & - & - & - \\
Camote & - & 14.86 & - & 15.74 & - \\
Oca & - & - & 14.86 & - & 15.74 \\
Achira & - & 14.86 & 14.86 & 15.74 & 15.74 \\
Mashua & - & 3.30 & 3.30 & 3.50 & 3.50 \\
Sunflower oil & 4.72 & 4.72 & 4.72 & 5.00 & 5.00 \\
Eggs & 23.58 & 23.58 & 23.58 & 24.99 & 24.99 \\
Skim Yogurt & 32.08 & 32.08 & 32.08 & 33.98 & 33.98 \\
Bakery powder & 0.94 & 0.94 & 0.94 & 1.00 & 1.00 \\
Sweetener & - & - & - & - & - \\
sugar & 5.66 & 5.66 & 5.66 & - & - \\
sucralose & - & - & - & 0.06 & 0.06 \\
\hline
\end{tabular}

Control: muffin with wheat flour and sugar, CAMa: muffin with camote, achira, mashua flours and sugar, OAMa: muffin with oca, achira, mashua flours, and sugar, CAMe: muffin with camote, achira, mashua flours, and sucralose, OAMe: muffin with oca, achira, mashua flours, and sucralose).

For the elaboration of the muffins, dry and liquid components were mixed in a food processor (Thermomix TM, Wuppertal, Germany), at 1 r.p.m. for 45 s. The dough was divided in $20 \mathrm{~g}$ portions and placed into the muffin mold; cooking was carried out in an oven (Zucchelli Mini Fanton, Medley, FL, USA) at $140^{\circ} \mathrm{C}$ for $15 \mathrm{~min}$. Then, muffins were cooled at room temperature for one hour and packed individually in heat-sealed food-grade plastic bags until analysis.

\subsection{Proximate Analyses}

Proximate composition (moisture, ash, protein, and fat) was evaluated following the official AOAC methods 2005 [28]. The determination of dietary fiber was carried out by the enzymatic-gravimetric method using a commercial kit (TDF-100A, SigmaAldrich, Darmstadt, Germany) (AOAC 985.29, 1997) [29]. Total carbohydrate content was 
determined by difference. All determinations were performed in triplicate using three samples for each treatment.

\subsection{Energy Value}

Calorie content was estimated $\times 100 \mathrm{~g}$, as the overall sum of calories of the individual components is the energy value for each component: fat $(\times 9 \mathrm{kcal} / \mathrm{g})$, protein $(\times 4 \mathrm{kcal} / \mathrm{g})$, carbohydrate $(\times 4 \mathrm{kcal} / \mathrm{g})$ and fiber $(\times 2 \mathrm{kcal} / \mathrm{g})$ contents. Values were estimated by the Atwater system.

\section{5. $p H$, Acidity and Water Activity}

The $\mathrm{pH}$ of muffins was measured using a digital $\mathrm{pH}$-meter (HANNA HI 9126, RI, USA). The acidity was determined by titration with $\mathrm{NaOH} 0.1 \mathrm{~N}$, using phenolphthalein as an indicator according to the methodology described in AOAC (2005) [28]. Water activity (aw) was determined using an aqueous activity meter (Aqualab 3rd Series, Decagon Devices Inc., Pullman, WA, USA), by the dew point method. All tests were carried out in triplicate.

\subsection{Moisture}

Moisture content was performed in the unbaked dough and after baking to evaluate moisture loss. Moisture was determined by drying in a stove at $105^{\circ} \mathrm{C} \pm 2$. For each measurement, approximately $3 \pm 0.001 \mathrm{~g}$ of the crumb was used. Moisture loss during baking was calculated by difference.

\subsection{Specific Volume (Vs)}

Specific volume was determined as the ratio of volume and weight $\left(\mathrm{cm}^{3} / \mathrm{g}\right)$ according to AACC Method 10-05.01. The height of the muffins was measured using a digital caliper from the bottom to the highest top. Four muffins of each formula were analyzed.

\subsection{Texture Profile Analysis (TPA)}

Crumb texture analysis was performed in a texturometer (PRO CT3 BROOKFIELD, Scarsdale, NY, USA) equipped with the TA4/1000 probe. For the determination, two slices $2 \mathrm{~cm}$ high from the middle part of each muffin were obtained. Slices were subjected to a deformation of $20 \%$ at a speed of $1 \mathrm{~mm} / \mathrm{s}$ [13]. The parameters evaluated were Hardness (peak maximum force on the first compression, $\mathrm{N}$ ), Cohesiveness (the ratio of positive areas in the two compression cycles representing the work required to compress the food for a second time as compared with that which was necessary to compress it for the first time, dimensionless), Springiness (the height that the food recovers after the first compression, $\mathrm{mm}$ ) and Chewiness (the product of hardness $\times$ cohesiveness $\times$ springiness, $\mathrm{N} \times \mathrm{mm}$ ). Ten measurements were performed for each sample. Analyses were performed on days 1 , 3 and 5 of storage.

\subsection{Color}

Crumb color analysis was performed with a colorimeter (Lovibond, LC100, USA) using the CIELAB ${ }^{\circledR}$ color scale for parameters $\mathrm{L}^{*}, \mathrm{a}^{*}$, and $\mathrm{b}^{*}$. In addition, the whiteness index was determined according to the equation $W I=100-\left[\left(100-L^{*}\right)^{2}+\left(a^{* 2}+b^{* 2}\right)\right]^{1 / 2}[30]$. At least 15 measurements were performed, being the average the reported value. Samples were maintained at room temperature $\left(\sim 18{ }^{\circ} \mathrm{C}\right)$ and relative moisture of $\sim 85 \%$. Analyses were performed on days 1, 3 and 5 of storage.

\subsection{Rheological Test}

The viscoelastic behavior of doughs was determined at $25^{\circ} \mathrm{C}$ using a rheometer (MCR102, Anton Paar, Graz, Austria) equipped with a plate-plate probe (40 $\mathrm{mm}$ diameter). The gap between the plates was set at $1 \mathrm{~mm}$. Due to the consistency of the dough, a frequency sweep test was performed in a range of 0.1 to $10 \mathrm{~Hz}$, stress at $3.3 \mathrm{~Pa}$, and frequency of 
$1 \mathrm{rad} / \mathrm{s}$ [31]. Storage modulus $\left(\mathrm{G}^{\prime}\right)$ and loss modulus $\left(\mathrm{G}^{\prime \prime}\right)$ were recorded. All rheological determinations were performed in triplicate.

\subsection{Microbiological Analysis}

Ten grams of muffin crumb were aseptically placed into a sterile stomacher bag and homogenized with $90 \mathrm{~mL}$ of buffered $0.1 \%$ peptone water (Difco, Le Pont de Claix, France) in a stomacher homogenizer (Model 400C, Seward, London, UK) for $1 \mathrm{~min}$, at room temperature. For each treatment, appropriate serial decimal dilutions were prepared: viable aerobic mesophilic microorganisms on pour plates of PCA agar (Difco, Le Pont de Claix, France) incubated at $30^{\circ} \mathrm{C}$ for $72 \mathrm{~h}$; mold and yeast on spread plates of Potato Dextrose Agar (PDA) (Difco) incubated at $25^{\circ} \mathrm{C}$ for $48 \mathrm{~h}$ (AOAC 986.32); Enterobacteriaceae on double layered plates of Violet Red Bile Glucose Agar (VRBG) (Acumedia, Lansing, MI, USA) incubated at $30{ }^{\circ} \mathrm{C} / 48 \mathrm{~h}$ (AOAC 2003.01), and Staphylococcus aureus on Baird Parker agar (Difco) incubated at $30^{\circ} \mathrm{C}$ for $48 \mathrm{~h}$ (AOAC 975.55). All analyses were performed in triplicate. The tests were carried out for five days. Analyses were conducted on days 1, 3 and 5 of storage.

\subsection{Sensory Analysis}

Muffins prepared from ACF were evaluated by a trained panel of 20 judges, men and women within the age-range of 18 to 25 years old, who are part of the team of athletes of the Technical University of Ambato. The panel received some training notions in previous sessions; the panelists were asked to assess attributes such as odor, flavor, texture and acceptability. The sensory test was performed using a 5-point hedonic scale (5-liked very much; 4-like moderately; 3-neither liked nor disliked; 2-disliked moderately; 1 -disliked very much). Five samples (one of each formulation, coded with three digits and presented in random order) were served to each panelist accompanied by water to allow palate cleansing between samples. Analyses were carried out on days 1, 3 and 5 of storage.

\subsection{Statistical Analysis}

Results were expressed as the mean \pm standard deviation (SD) for each parameter. The experimental design of a single completely randomized factor was applied. Statistical analysis was performed with the GraphPad Prism 5.0 program (GraphPad Software, San Diego, CA, USA) for the one-way ANOVA variance analysis. To determine significant differences $(p<0.05)$, Tukey's test was applied.

\section{Results}

Previous studies were conducted with different formulations of camote, achira, oca and mashua flour blends (based on a baker percentage) in order to obtain products with proper volume, taste and flavor. The selected formulations are shown in Table 1.

\subsection{Proximate Composition of Muffins}

The use of ACF to formulate gluten-free muffins resulted in differences in the proximate composition (Table 2). Moisture was similar in all formulations $(p>0.05)$ despite the clear differences between the Control batch and ACF muffins, e.g., in terms of protein and fiber content. The protein content showed significant differences $(p<0.05)$ mainly due to the percentage of protein in Andean flours, which is lower than in wheat flour (Table 2), as generally occurs with gluten-free flours and starches [32], except when formulated with legumes [9], in which the protein content is increased. The fat content was lower in ACF muffins than in the Control $(p<0.05)$ due to the low presence of fat in the tubers (camote, mashua and oca) and achira flours. It should be noted that the low percentage of fat in muffins may represent significant reductions in fat caloric value, as well as eventually low aeration, fragile structure, loss of moisture and small heat transfer [33]. Regarding carbohydrates, the highest value corresponded to the Control (wheat) muffins (51.6\%) 
$(p<0.05)$, although in CAMa and OAMa muffins similar values were recorded $(\approx 48-49 \%)$. A lower content of carbohydrates was found in formulations in which sugar was replaced by a synthetic sweetener such as sucralose (CAMe and OAMe) $(p<0.05)$. However, it is worth noting a prominent increase in fiber in all formulations containing ACF compared with the Control (for example, $1.78 \%$ vs. $14.6 \%$ in Control and OAMe, respectively). In this connection, the fiber content of ACF muffins would allow them to be labeled as "High in dietary fiber," in concordance to the Codex and EU Regulation (CE) N $\mathrm{N}^{\circ} 1924 / 2006$, which establishes that a solid food must contain a minimum of $6 \mathrm{~g}$ of dietary fiber per $100 \mathrm{~g}$. In the present work, all formulations met this requirement, except for the Control, elaborated with wheat flour; the lowest fiber content was found in OAMa muffins, and the highest in the same formulation but when sucralose was used as a sweetener (OAMe). Even though, sucralose as an ingredient contains resistant maltodextrin (which is considered a dietetic fiber, FDA, 2018), in view of the very small concentration of this compound in the muffins, its effect is expected to be negligible. Ash contents of all ACF samples were significantly higher than those of the Control, finding a slight difference in CAMa with respect to the rest $(p<0.05)$. The ashes in ACF muffins could be attributed to the content of minerals such as calcium, potassium, iron, phosphorus, among others, which are found in these Andean flours (3.3\% in oca flour and $1.32 \%$ in camote flour) [34-36]. In terms of caloric content, the energy provided by ACF muffins was lower than that of the Control made with wheat flour $(p<0.05)$, in a proportion ranging between $8 \%$ and $15 \%$. The main difference lies in the fact that the muffins made with wheat flour contained more protein and lipids, and in some cases more carbohydrates, about $10 \%$, while the other formulas mainly presented a greater fiber content. Even so, the differences in energy content were not very notable and, on the other hand, it was somewhat less balanced in the case of ACF muffins because the World Health Organization [37] recommended that in order to have a balanced diet, the fat-percentage intake should constitute $15-30 \%$ and no more than $10 \%$ should come from saturated fats, proteins should account for $10-15 \%$ of the total diet energy, and carbohydrates should account for around $55-75 \%$.

Table 2. Proximate composition (\%), caloric content (Kcal/100 g), $\mathrm{pH}$, acidity (as \% of lactic acid) and aw of glutenfree muffins.

\begin{tabular}{|c|c|c|c|c|c|}
\hline Parameters & Control & CAMa & OAMa & CAMe & OAMe \\
\hline Moisture & $36.95 \pm 0.07^{\mathrm{a}}$ & $37.14 \pm 0.40^{\mathrm{a}}$ & $37.10 \pm 0.42^{a}$ & $37.28 \pm 0.72^{\mathrm{a}}$ & $37.14 \pm 0.76^{\mathrm{a}}$ \\
\hline Protein & $3.99 \pm 0.05^{\mathrm{a}}$ & $1.92 \pm 0.04^{\mathrm{d}}$ & $1.82 \pm 0.02^{\mathrm{d}}$ & $2.33 \pm 0.03^{b}$ & $2.09 \pm 0.05^{c}$ \\
\hline Fat & $4.43 \pm 0.05^{\mathrm{a}}$ & $2.15 \pm 0.03^{d}$ & $3.33 \pm 0.03^{b}$ & $2.58 \pm 0.05^{\mathrm{c}}$ & $3.45 \pm 0.06^{\mathrm{b}}$ \\
\hline Fiber & $1.80 \pm 0.06^{\mathrm{e}}$ & $8.38 \pm 0.02^{c}$ & $5.89 \pm 0.28^{d}$ & $13.68 \pm 0.08^{b}$ & $14.69 \pm 0.04^{\mathrm{a}}$ \\
\hline Ash & $1.12 \pm 0.06^{\mathrm{c}}$ & $2.44 \pm 0.04^{b}$ & $2.72 \pm 0.09^{\mathrm{a}}$ & $2.70 \pm 0.03^{\mathrm{a}}$ & $2.83 \pm 0.05^{\mathrm{a}}$ \\
\hline Carbohydrates & $51.72 \pm 0.29^{\mathrm{a}}$ & $47.97 \pm 0.49^{b}$ & $49.14 \pm 0.80^{b}$ & $41.43 \pm 0.85^{\mathrm{c}}$ & $39.80 \pm 0.94^{\mathrm{c}}$ \\
\hline Calories (Kcal/100 g) & $266.29 \pm 0.39^{a}$ & $235.67 \pm 0.93^{c}$ & $245.58 \pm 0.18^{b}$ & $225.62 \pm 1.56^{\mathrm{e}}$ & $227.98 \pm 0.27^{\mathrm{d}}$ \\
\hline $\mathrm{pH}$ & $7.96 \pm 0.28^{c}$ & $7,44 \pm 0.14^{\mathrm{a}, \mathrm{b}}$ & $7.59 \pm 0.23^{b}$ & $7.31 \pm 0.03^{\mathrm{a}}$ & $7.65 \pm 0.08^{b}$ \\
\hline Acidity & $0.06 \pm 0.01^{\mathrm{a}}$ & $0.08 \pm 0.01^{\mathrm{c}}$ & $0.07 \pm 0.01 \mathrm{bc}$ & $0.08 \pm 0.03^{c}$ & $0.07 \pm 0.03^{a b}$ \\
\hline $\mathrm{a}_{\mathrm{w}}$ & $0.947 \pm 0.002^{b}$ & $0.929 \pm 0.003^{\mathrm{a}}$ & $0.948 \pm 0.002 \mathrm{bc}$ & $0.945 \pm 0.002^{b}$ & $0.957 \pm 0.001^{\mathrm{c}}$ \\
\hline
\end{tabular}

Control: muffin with wheat flour and sugar, CAMa: muffin with camote, achira, mashua flours and sugar, OAMa: muffin with oca, achira, mashua flours and sugar, CAMe: muffin with camote, achira, mashua flours and sucralose, OAMe: muffin with oca, achira, mashua flours and sucralose) Results are the mean \pm standard deviation. Different letters $(a, b, c)$ in the same line indicate significant differences between samples $(p \leq 0.05)$.

The muffins developed in this work showed a low saturated fat content $(\mathrm{g} / 100 \mathrm{~g})$ of 0.74 in the Control, 0.37 in CAMa, 0.59 in OAMa, 0.44 in CAMe and 0.61 in OAMe, determined from the saturated fat content of the ingredients (flours from Andean crops $0.01 \mathrm{~g} / 100 \mathrm{~g}$; sunflower oil $10.1 \mathrm{~g} / 100 \mathrm{~g}$; eggs $2.8 \mathrm{~g} / 100 \mathrm{~g}$ and skimmed yogurt $0.21 \mathrm{~g} / 100 \mathrm{~g}$ ). According to the nutrition claim related to saturated fats, solid foods that do not contain more than $1.5 \mathrm{~g}$ of saturated fat per $100 \mathrm{~g}$ could be labeled as "low in saturated fat" (EU Regulation 1924/2006) [38]. 


\section{2. $p H$, Acidity Values and Water Activity}

The $\mathrm{pH}$ values showed significant differences among the formulations (Table 2). All samples showed values greater than $7(p<0.05)$, being the control the sample presenting the highest $\mathrm{pH}$ value (7.96). All muffins would be considered alkaline foods, which is a representative characteristic of bakery products, as was reported by Khalifa, et al. [2]. Alkalinity is mainly attributed to the components of the formulations, mostly flours ( $35 \%$ $w / w)$ and eggs with a $\mathrm{pH}$ of 8 , values that together provide this property to muffins. Acidity values, due to the presence of yogurt in the formulation, showed slight variations of lactic acid within a very narrow range $(p<0.05)$. Muffins with camote flour were slightly more acid that those with oca or wheat flours; camote flour has an acidity of $0.096 \%$, highlighting that this tuber has components such as folic and ascorbic acid, among others, which confer a characteristic acidity $[39,40]$. Likewise, acidity in oca and mashua is related to the degree of maturity of the tuber. Furthermore, sweet flavor is enhanced when tubers are exposed to sunlight, which, in addition to transforming the starches in sugars, decreases the oxalic acid present to around $47 \%$ [41], consequently decreasing acidity.

$\mathrm{a}_{\mathrm{w}}$ was higher than 0.92 in all formulations $(p<0.05)$. This parameter indicates the free water in the product and is therefore decisive for the possible growth of microorganisms. In this work, muffins with sugar have aw values between $\sim 0.93$ and 0.95 , and between 0.94 and 0.96 in those with sucralose. These results are in concordance with Chisamore [42], who reported values of 0.95 for cupcakes with 50\% sugar substituted with sweetener and 0.92 in the control with sugar. $a_{w}$ decreased with the incorporation of black carrot pomace in muffins, possibly due to the absorption capacity of fiber [31], the same was observed with the inclusion of jambolan (Syzygium cumini) and xhantan gum in rice muffin formulations, which contributed to an increased shelf-life of these products [31]. This slight decrease in aw, in the present work, is only observed in the CAMa sample, but it does not seem that the presence of a higher fiber content in the other muffins favors water absorption (Table 2).

\subsection{Moisture before and after Baking}

Table 3 shows the moisture of the raw dough as well as the loss of moisture during baking. The moisture content showed values higher than $49 \%$, and no effect on moisture was observed with the incorporation of ACF in the formulations $(p>0.05)$. In general, muffins, cupcakes and biscuits, among others, come from fluffy, liquid and creamy doughs, so they are quite moist and pasty to the touch due to the amount of liquids and fats that are incorporated into the flours [43]. Man, et al. [14], reported that values of moisture content in gluten-free muffins formulated with rice and soya flours and corn starch were about $20-31 \%$, lower than those found in the present work (Table 3). Those authors stated that moisture in muffins increased with the increase of soy flour, because soy and rice flours absorb a higher quantity of water. The ability of proteins and carbohydrates to hold water against gravity is attributed to their hydrophilic parts such as polar or charged side-chains [44]. Similarly, Palacio, et al. [13] reported that the incorporation of squash seed flour in gluten-free premix muffins increases moisture, fact attributed to the high fiber content of the flours.

The moisture loss during baking ranged from $11.91 \%$ to $15.03 \%$, in CAMa and OAMe muffins, respectively. During baking, the content of reducing sugars, sucrose, and proteins in the doughs gives rise to reactions such as caramelization and the Maillard reaction, which could cause the formation of an outer crust that prevents moisture loss during this process [6]. In the present work, the moisture loss values for Andean crop muffins were higher than the $11.78 \%$ reported by Goswami, et al. [45] when baking Barnyard millet based muffins in a preheated conventional oven at $\left(200^{\circ} \mathrm{C}\right.$ for $6 \mathrm{~min}$, followed by $6 \mathrm{~min}$ at $\left.175^{\circ} \mathrm{C}\right)$, which is a more intense baking than that of the present work $\left(140^{\circ} \mathrm{C}\right.$ for $\left.14 \mathrm{~min}\right)$. 
Table 3. Percentage of moisture in the raw dough and moisture lost during baking.

\begin{tabular}{cccc}
\hline Sample & $\begin{array}{c}\text { Moisture in the Raw } \\
\text { Dough } \\
\mathbf{( \% )}\end{array}$ & $\begin{array}{c}\text { Moisture of the } \\
\text { Crumb } \\
\mathbf{( \% )}\end{array}$ & $\begin{array}{c}\text { Moisture Lost during } \\
\text { Baking } \\
\mathbf{( \% )}\end{array}$ \\
\hline Control & $49.70 \pm 0.68^{\mathrm{a}}$ & $37.61 \pm 0.56^{\mathrm{ab}}$ & $12.09 \pm 0.98^{\mathrm{a}}$ \\
CAMa & $50.23 \pm 0.05^{\mathrm{a}}$ & $38.32 \pm 0.28^{\mathrm{a}}$ & $11.91 \pm 0.93^{\mathrm{a}}$ \\
OAMa & $50.34 \pm 0.85^{\mathrm{a}}$ & $36.95 \pm 0.36^{\mathrm{b}}$ & $13.39 \pm 0.36^{\mathrm{ab}}$ \\
CAMe & $50.69 \pm 0.86^{\mathrm{a}}$ & $37.31 \pm 0.18^{\mathrm{b}}$ & $13.38 \pm 0.95^{\mathrm{ab}}$ \\
OAMe & $50.74 \pm 0.21^{\mathrm{a}}$ & $35.71 \pm 0.12^{\mathrm{b}}$ & $15.03 \pm 0.26^{\mathrm{b}}$ \\
\hline
\end{tabular}

Control: muffin with wheat flour and sugar, CAMa: muffin with camote, achira, mashua flours and sugar, OAMa: muffin with oca, achira, mashua flours and sugar, CAMe: muffin with camote, achira, mashua flours and sucralose, OAMe: muffin with oca, achira, mashua flours and sucralose) Results are the mean \pm standard deviation. Different letters $(a, b)$ in the same column indicate significant differences between samples $(p \leq 0.05)$.

\subsection{Specific Volume (Vs)}

The vs. value is a useful parameter for the evaluation of the quality of bread and bakery products. Generally it is defined by the relationship between the volume and weight of the product $[3,12]$. The results of the vs. in this study showed that ACF muffins were smaller that the control ones, except for CAMe $(p<0.05)$ (Figure 1). A high water holding capacity is related to an increase in muffin height during baking, being the highest values for wheat muffins compared with muffins formulated with wheat, rice and quinoa [18]. On the contrary, specific volume and height decreased with the increase of black carrot pomace [15] or jambolan (Syzygium cumini) [31] in muffins due to the presence of fiber, since when added, it reduces the volume and height of the muffins. These results were consistent with those found in the present work, except for CAMe. Accordingly, Zahn, et al. [46] reported that the replacement of fat with increasing amounts of dietary fiber as inulin increased the muffin moisture and crumb density, while muffin volume decreased. However, the volume of muffins was not affected by the incorporation of yacon (Smallanthus sonchifolius), a non-starchy Andean root, in the formulation [47].

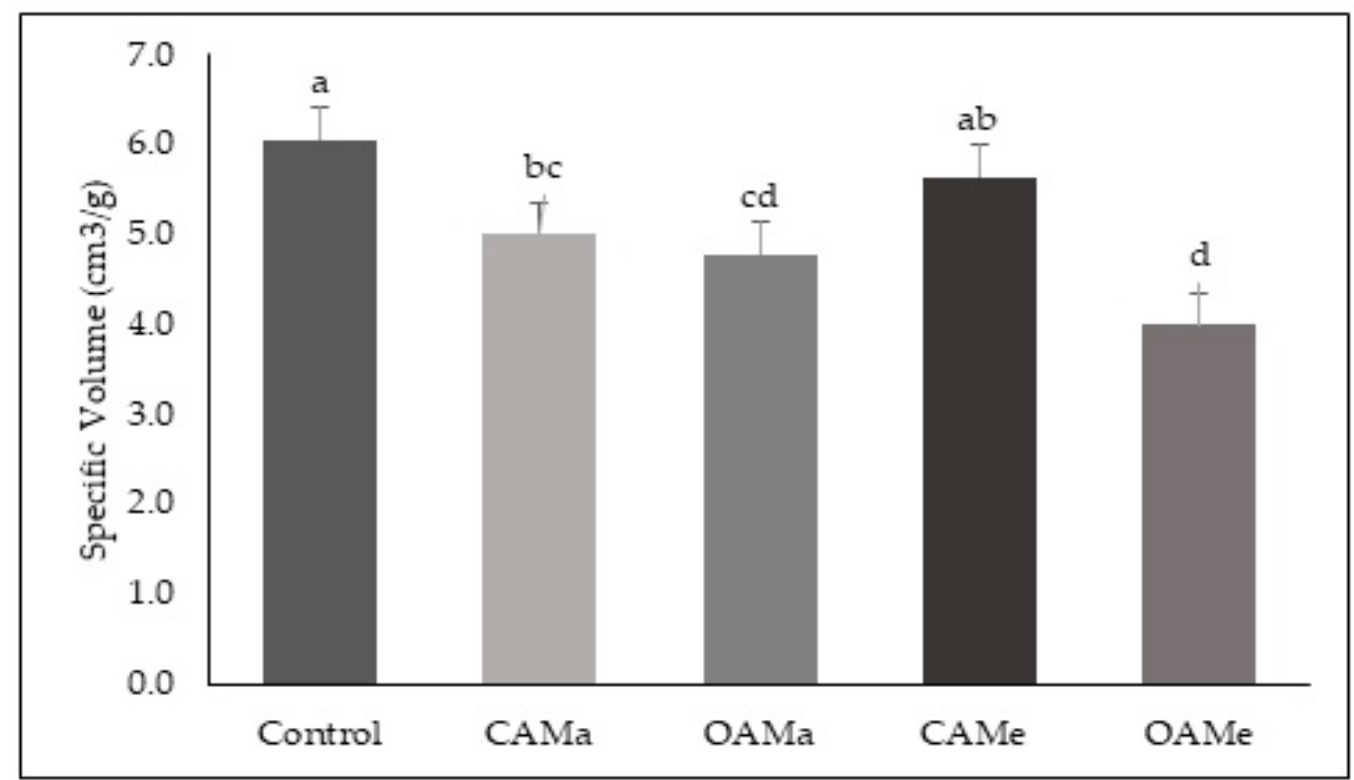

Figure 1. Specific volume of muffin. Different letters in the same graphics indicate significant differences $(p<0.05)$.

Having higher volumes is of interest in the bakery industry because this parameter often attract customers [48]. In this sense, it is essential to note that samples produced with ACF had an attractive volume, ranging from 4 to $5 \mathrm{~cm}^{3} / \mathrm{g}$, with up to a $17 \%$ volume reduction in comparison with the Control samples, despite the fact that, to the naked eye, 
there was hardly any difference (Figure 2). CAMa muffins were not high but wide, which can also be attractive in a certain way. The reduction in volume could be because ACF does not contain gluten to form the matrix structure in the mixed process, which is responsible for retaining the gas produced during the activation of the baking powder [13]. In addition, fiber (which was in a much greater amount in ACF muffins) could collapse $\mathrm{CO} 2$ bubbles during baking, thus reducing the volume [49]. Belorio, et al. [32] argued that despite wheat flour is usually employed in cakes, the gluten network is not regularly developed within this application because of the presence of certain ingredients (sugar and fat) that hinder the interaction of the gluten-forming proteins, partly due to the lower amount of wheat flour used (if it was the case) and also because of the low mechanical energy applied by the mixing whiskers during the mixing step. Muffins and other pastry products do not need the continuous network, so the production of gluten-free versions is easier, unlike bread, pasta and some cookies that require a gluten network development, in which case it is often necessary to use a hydrocolloid [50].

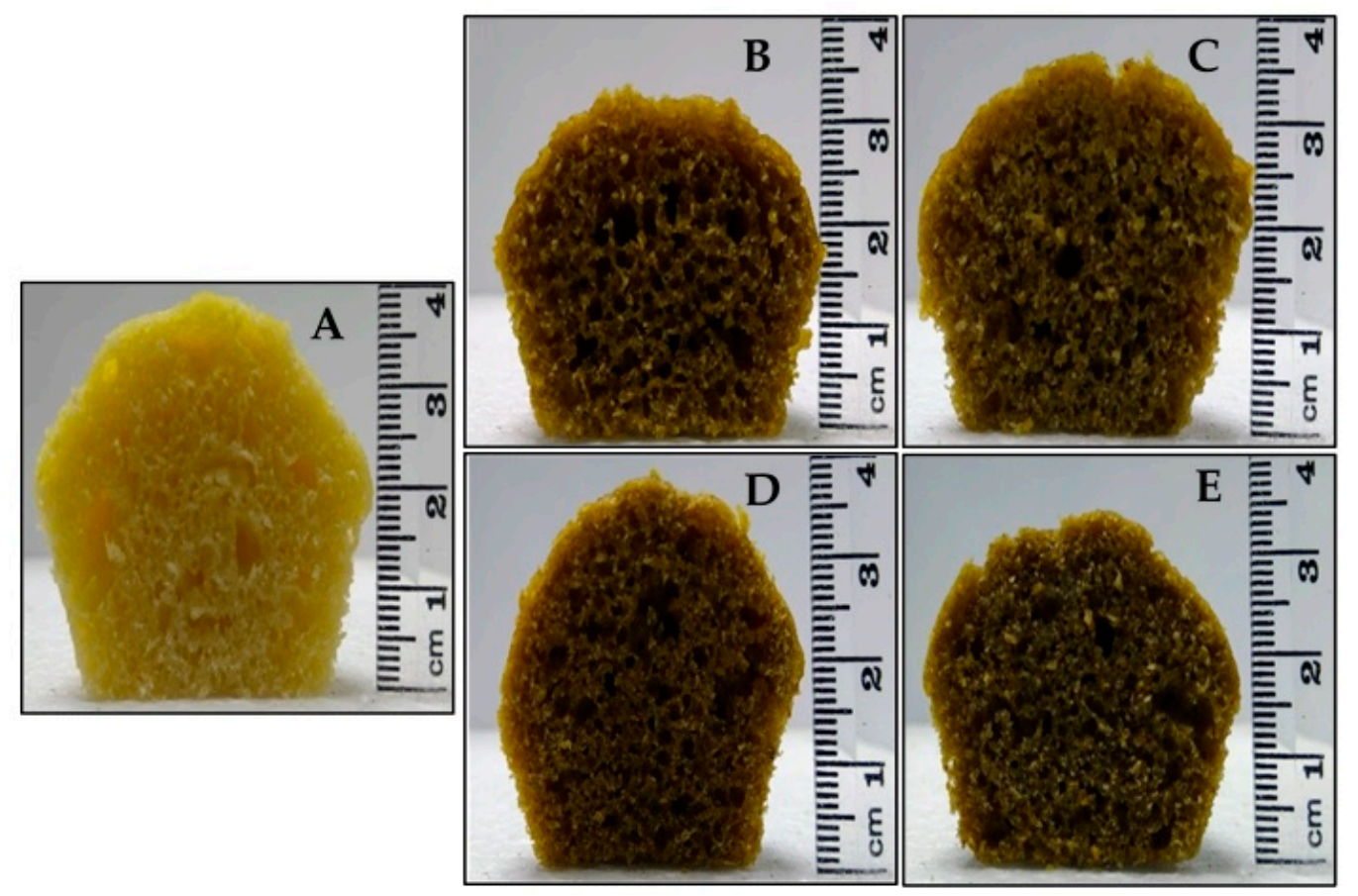

Figure 2. Muffin color and crumb structure images (A): control, (B): CAMa, (C): OAMa, (D): CAMe, (E): OAMa.

\subsection{Visual Appearance and Color}

Essential parameters in new or alternative products that customers take into account are appearance and color, which mainly depend on the type of flour, the quality and quantity of the ingredients and their interactions, as well as on the temperature and time of baking $[6,15]$.

In the present work, muffins were clearly differentiated in terms of appearance, being the most noticeable difference the blond color of the control batch (wheat flour) whereas the others (Andean crops), reminded of cakes containing a certain amount of chocolate or made with whole-grain flour (Figure 2). Regarding the appearance of the sponge cake, all muffins looked very similar, with spongy dough of a similar hollow size.

The instrumental measurement of color was carried out just on the crumb since no evident differences with the crust were observed (Figure 3). $\mathrm{L}^{*}$ value was almost halved in ACF muffins compared with that of the control, in contrast with the $a^{*}$ value, which was higher in all wheat-free formulations $(p<0.05)$. Accordingly, Lancetti, et al. [47] reported that the crust of gluten-free muffins made with $5 \%$ and $10 \%$ corn starch replaced by yacon (Smallanthus sonchifolius) showed that $\mathrm{L}^{*}$ decreased while the $\mathrm{a}^{*}$ index rose with increasing 
concentrations of the root in the formulation. These authors indicated that the behavior in the crumb was similar, and that an increase in the $b^{*}$ parameter was also detected in muffins. In the present work, a lower yellowness $\left(b^{*}\right)$ was also observed in ACF muffins, especially in the formulations with camote (CAMa and CAMe) $(p<0.05)$.
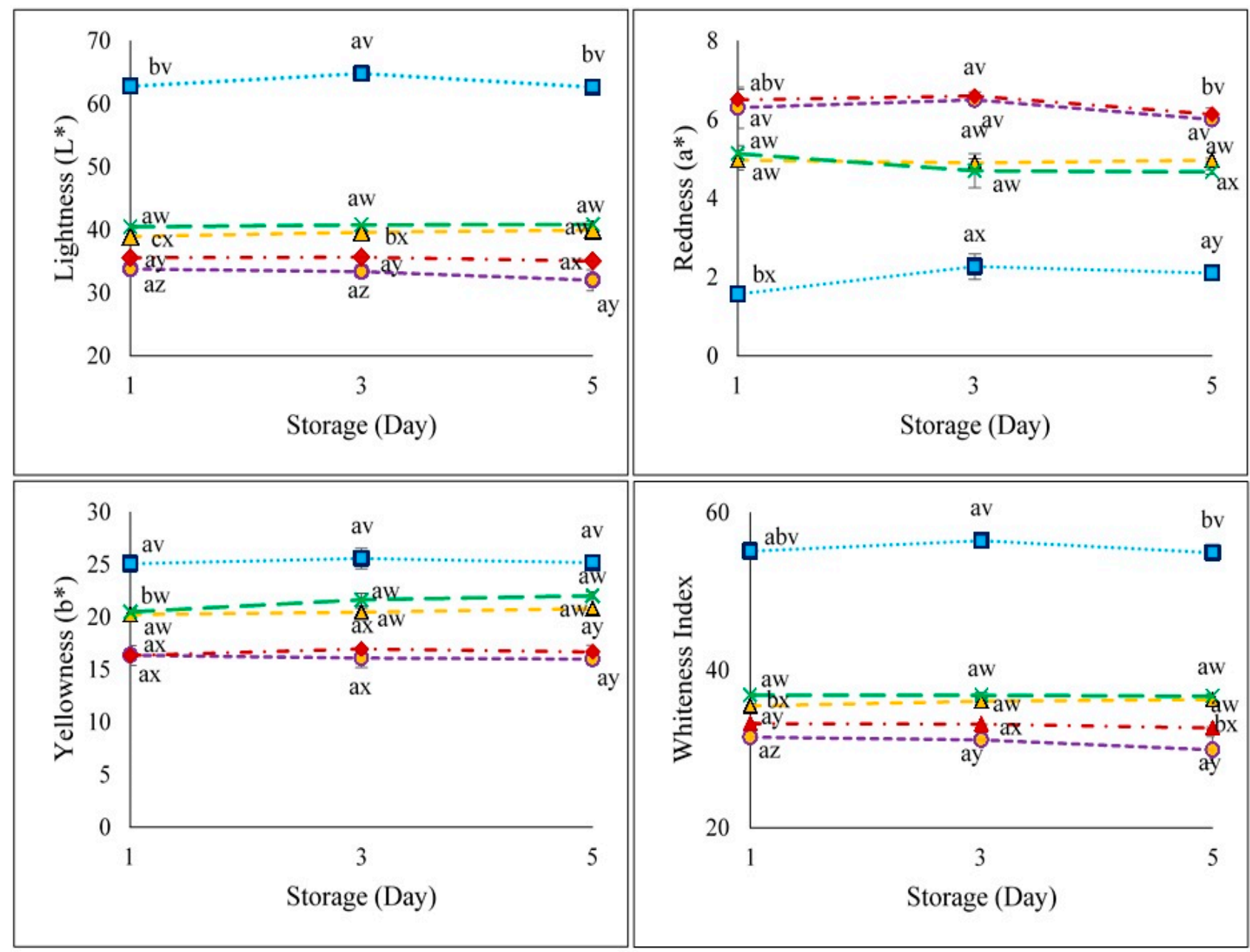

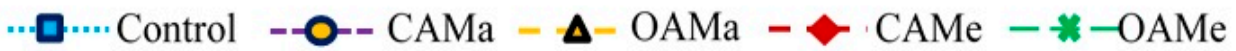

Figure 3. Color properties of muffin. Results are the mean \pm standard deviation. Two-way ANOVA: Different letters (a,b, c) show significant differences for each lot at different time $(p<0.05)$. Different letters $(\mathrm{w}, \mathrm{x}, \mathrm{y})$ show significant differences among samples at same time $(p<0.05)$.

As expected in view of the values obtained for the above parameters, whiteness registered higher values in the control $(p<0.05)$; ACF muffins showed a brown color which could be attributed to the content of natural sugar and pigments such as carotenoids $(\alpha-\beta$-carotenes) and anthocyanins (cyanidines, pelargonidine and peonidines) [25,51], and also to the fiber content in the ACF used for each formulation. The inclusion of black carrot pomace to muffins made of rice had a greyish-purple color due to presence of anthocyanin pigments, and conferred a dark color to the muffins (decreased $\mathrm{L}^{*}, \mathrm{a}^{*}$ when added at $6 \%$ and $b^{*}$ values) [15]. Similarly, the incorporation of jambolan (Syzygium cumini) in rice muffins decreased $L^{*}, a^{*}$ and $b^{*}$ values, giving rise to darker muffins and even conferring a greenish color due to the presence of anthocyanin [31] as a natural color agent. Pigments could be also contributed to the caramelization and Maillard reaction [14,52], which takes place during flour preparation and baking when the reducing sugars and proteins are heated together. 
Since all formulations were elaborated under the same conditions, the results allow concluding that the addition of ACF resulted in muffins with brownish color (resembling chocolate). Consumers consider darker muffins as being healthier than light ones [49]. In this sense, gluten-free bread used to be light in appearance, especially in those based on starch, and consumers perceived it as highly purified, with a low content of minerals and fiber. Therefore, the addition of some ingredients to reduce lightness could be good from a marketing point of view [53]. Browning was favored by the increase of fiber content, as was reported by Baixauli, et al. [54] who showed that the addition of peach fiber darkened the muffins. In this connection, $\mathrm{L}^{*}$ values increased in cake crumbs when inulin (carbohydrate nature) was added in the formulation at different ranges (35-100\%) as a fat replacer, while in the crust, $\mathrm{L}^{*}$ and $\mathrm{b}^{*}$ values decreased and $\mathrm{a}^{*}$ increased [55]. These authors attributed this fact to the reducing sugars in inulin and to the possible further hydrolysis of low molecular weight fructan to fructose, involved in the Maillard reaction during baking. Similarly, the substitution of wheat flour and/or the inclusion of some ingredients as potatoes peels (extruded or not, 25\%) [56], enzymatically treated banana flour in 10-70\% ratio [57] or squash seed flour in $20 \%$ [13], are reported to result in muffins with a darker color. Color evolution was assessed in the muffins during the 5 days of storage, but no remarkable changes were evident in any of the parameters, although occasionally there were certain significant differences (Figure 3).

\subsection{Texture Profile Analysis}

The texture profile analysis of the muffins is shown in Figure 4. These attributes are very important as they reflect the quality and freshness of the product. Hardness is defined as the highest force required to compress the muffin crumb under a constant deformation [6]. Cohesiveness quantifies the stress of the structure in order to determine the level of tolerance in handling and packaging [15]. Springiness, defined as the elasticity of the muffins, is also crucial for baked products associated with an elastic and fresh aerated product [9]. The inclusion of ACF shows a significant effect $(p<0.05)$ on TPA parameters of the muffin crumb (Figure 4). There was a notorious greater firmness, in comparison with the control sample, more evident in camote formulations, especially the one containing sucralose CAMe $(p<0.05)$ on the first day. As previously mentioned, the presence of gluten in the control (responsible for gas retention during dough growth) and the lower fiber content (which could collapse $\mathrm{CO} 2$ during baking) could be the cause of a lower firmness in the control, as the moisture contents of the doughs were similar $(p>0.05)$ (Table 3). Moreover, changes in firmness (Figure 4) could also be caused by the rupture of emulsions, carbohydrate hydrolysis, loss of water or fat content and protein coagulation [58]. However, cohesiveness decreased with the use of ACF $(\approx 50 \%)$ and OAMe muffins presented the highest value for this parameter among the Andean formulations $(p<0.05)$, with lower values than the control. Springiness was reduced in formulations with sugar while the higher values were observed in OAMe and CAMe $(p<0.05)$, the latter with similar values to those of the control $(p<0.05)$. Sucralose provides sweetness but does not have the plasticizer and softening effect that sugar does [59] although this effect is not clearly seen in the present work (Figure 4). Chewiness values (directly proportional to firmness) were higher in ACF muffins, even more than twofold, compared with the control, especially in the case of the CAMa formulation (11.27 vs. 34.08 , respectively). All ACF formulations contained achira; the high amylopectin content of this root allows the formation of a strong polymeric matrix, while avoiding syneresis and giving stability to the formulated products [60]. Andean crops such as yacon in gluten-free muffins, showed a much lower firmness and chewiness than the control (corn starch), but present an opposite effect on cohesiveness [47]. These authors attributed this effect to the fructose and fructans (yacon is a source of $\beta-(2-1)$ fructo-oligosaccharides) that affects starch gel structure and therefore the mechanical properties. These compounds increased gel rigidity (as a result of decreased starch swelling and reduced amylose leaching) and also because the weakling effect on the egg network and starch structure, caused by the disruption of 
FOS particles among the components. Therefore, the texture of gluten-free products will be related to the specific compounds employed in the formulation. With the use of another Andean pseudocereal such as quinoa (Chenopodium quinoa), raising its concentration (above $25 \%$ ) increased firmness and chewiness in bread made with potato starch, buckwheat and rice flours [61]. Fortification of rice flour muffins with this same pseudocereal (quinoa) increased hardness, as well as gumminess and chewiness [18]. The results found in the present work are in agreement with those of Palacio, et al. [13], who reported that firmness and chewiness increase with increased fiber in gluten-free muffins with squash seed dietary fiber compared with control muffins (based on corn starch and rice flour), while cohesiveness and springiness were not affected. These authors pointed out that perhaps the concentration and kind of fiber used to produce the muffins (and also its effects on moisture retention) may influence the specific effects observed on the texture. Thus, firmness of the muffins also varies with the source of protein isolate incorporated as was reported by Shevkani, et al. [9]. In this regard, when black carrot pomace was included in rice muffins, a decrease in firmness and springiness was shown with increasing concentrations of the pomace, while the effect on cohesiveness and gumminess at the highest concentration $(9 \%)$ was the opposite [31]; in addition, the presence of xanthan gum in the aforementioned muffins influenced these parameters possibly by interacting with starch and affecting its retrogradation. The increase in firmness was inversely proportional to the percentage of jambolan (Syzygium cumini) included in rice muffins, while cohesiveness intensified with the incorporation of jambolan, and springiness was not affected [31]. In view of these results, the textural parameters depend entirely on the ingredients used to replace the original formulation and it is therefore not easy to find a general behavior. However, it seems that the presence of compounds with a high fiber content, such as Andean crops or certain types of protein, tends to increase the firmness and springiness of the resulting bakery products.

Texture parameters were also determined during storage (Figure 4). A progressive increase in firmness and chewiness was detected $(p<0.05)$, as well as a decrease in cohesiveness and springiness, and the behavior of these two parameters was slightly more evident in the Control lot after five days of storage. The retrogradation of starch, which refers to the recrystallization behavior of gelatinized starches during cooling and storage, could be eventually responsible for hardening and loss of moisture [62]. In this connection, the inclusion of potato peel (extruded or not) in cinnamon muffins reduced the number of air pockets and increased their density, thus increasing the compression force [56]. Cauvain [63], mentioned that hardening is produced by two simultaneous effects: moisture migration from the crumb towards the crust and the recrystallization of the starch that causes the intrinsic hardening of the wall material of the alveoli. In addition, it could be possible that the quality of the protein of the muffins contributes to these results because the swelling properties and viscoelastic hydration of the ACF are less than those of wheat flour [8].

\subsection{Rheological Test}

Rheological parameters $G^{\prime}, G^{\prime \prime}$ and $\tan \delta$ are shown in Figure $5 A-C$, respectively. Viscoelasticity is an essential physical property in products such as cupcakes or muffins, since these must have the capacity to form an ideal structure that retains gas inside the bubbles formed during shaking, kneading and baking processes; on the contrary, a too highly viscous batter can restrict its expansion during baking [64]. For all samples, the storage modulus $\left(G^{\prime}\right)$ and the loss modulus $\left(G^{\prime \prime}\right)$ raised with the increase in frequency and displayed a dominant liquid-like behavior [65]. The doughs showed G" values higher than $G^{\prime}$, indicating an unstructured and viscous behavior. The control sample displayed a viscous behavior as was observed by Zaidel, et al. [66] in gluten, adding a high protein content. Hence, the doughs studied in the present work showed a predominantly viscous response, indicating that the dough network was completely viscous [67]. The sweetener used had a slight effect on both $G^{\prime}$ and $G^{\prime \prime}$, being more evident in OAM formulations for al 
$\omega$ tested. Sucralose addition increased the values of $G^{\prime}$ and $G^{\prime \prime}$ moduli with respect to their counterparts made with sugar; similar results were observed by Abdel-Shafi, et al. [68] in dough cookies with sugar replaced by stevioside.
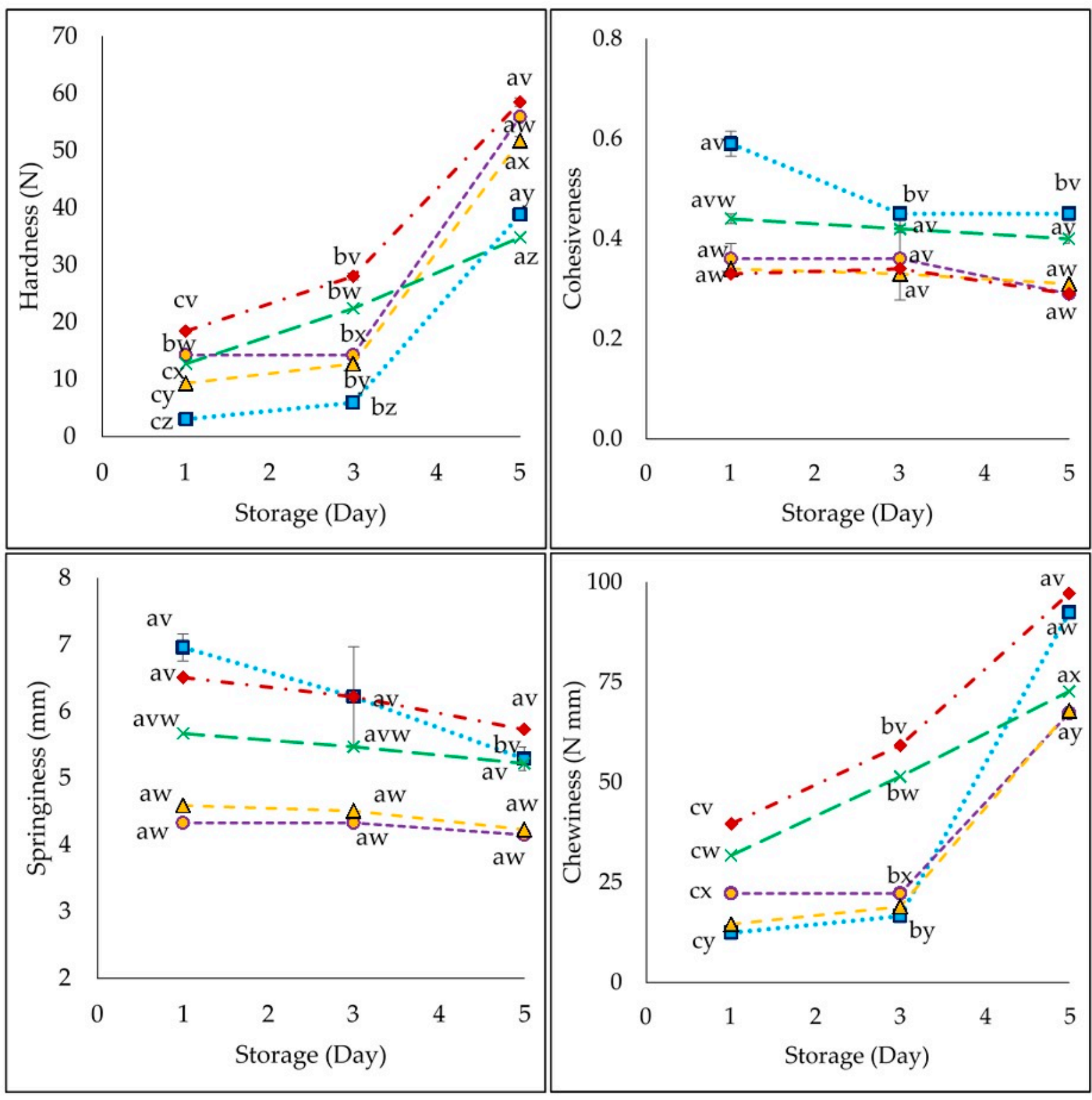

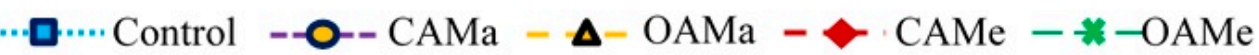

Figure 4. Textural properties of muffin. Results are the mean \pm standard deviation. Two-way ANOVA: Different letters (a, $\mathrm{b}, \mathrm{c})$ show significant differences for each lot at different time $(p<0.05)$. Different letters $(\mathrm{w}, \mathrm{x}, \mathrm{y})$ show significant differences among samples at same time $(p<0.05)$. 

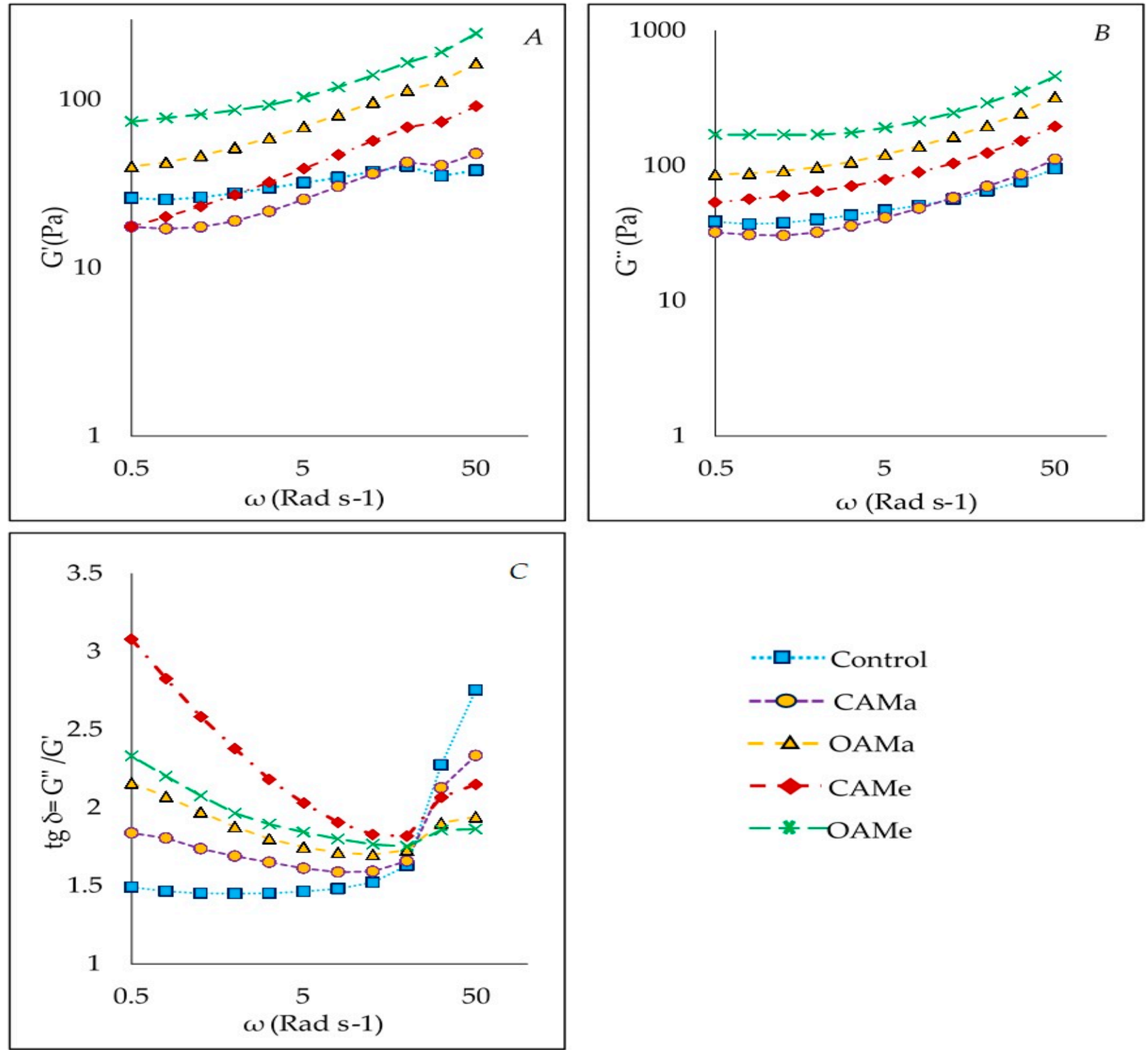

Figure 5. Rheological behavior of gluten-free muffins: (A) $\mathrm{G}^{\prime},(\mathbf{B}) \mathrm{G}^{\prime \prime}$, and (C) $\operatorname{tg} \delta$.

All dough samples had a $\tan \delta$ curve which tended to shift towards lower values (from 3 to 1.7). Therefore, $\tan \delta$ values for all dough formulations were higher than 1 , indicating that they were more liquid than solid-like materials. This behavior could be related to the ratio of the liquid phase used in the formulation which creates an emulsion type structure [69]. However, no information on doughs with these ingredients was available in the literature.

The parameters for power-law equations for all samples are shown in Table 4 . The rheological behavior indices, $\mathrm{n}^{\prime}$ and $\mathrm{n}^{\prime \prime}$ values were less than 1 , which is indicative of the pseudoplastic nature of the doughs. While $n^{\prime \prime}$ was almost double of that of $\mathrm{n}^{\prime}$ in the control, for CAMa it was similar. On the contrary, in OAMa, CaMe and OAMe the values of $n^{\prime \prime}$ were less than those of $\mathrm{n}^{\prime}$. Regarding the observed consistency values for the storage and loss equations, $K^{\prime \prime}$ was always higher than $K^{\prime}$ in all samples, but the $K^{\prime \prime} / K^{\prime}$ ratio was very different among samples, being the lowest in the control. The values of $K^{\prime}$ and $K^{\prime \prime}$ increased when sweetener was used, which indicates that sucralose led to a slightly stronger dough. 
Table 4. Rheological properties of dough of gluten-free muffins produced with ACF.

\begin{tabular}{|c|c|c|c|c|}
\hline Sample & $\mathbf{n}^{\prime}$ & $K^{\prime}\left(\right.$ Pa.s $\left.\mathbf{n}^{\prime}\right)$ & $\mathrm{n}^{\prime \prime}$ & $K^{\prime \prime}\left(\right.$ Pa.s $\left.{ }^{n^{\prime \prime}}\right)$ \\
\hline & \multicolumn{2}{|c|}{$\mathrm{G}^{\prime}=\mathbf{K}^{\prime} \cdot \boldsymbol{\omega}^{\mathbf{n}^{\prime}}$} & \multicolumn{2}{|c|}{$G^{\prime \prime}=K^{\prime \prime} \cdot \omega^{n^{\prime \prime}}$} \\
\hline $\mathrm{C}$ & $0.14 \pm 0.01^{\mathrm{d}}$ & $29.79 \pm 1.01^{c}$ & $0.21 \pm 0.01^{b}$ & $38.92 \pm 1.03^{d}$ \\
\hline CAMa & $0.26 \pm 0.02^{c}$ & $17.75 \pm 1.04^{\mathrm{e}}$ & $0.28 \pm 0.03^{a}$ & $30.07 \pm 1.07^{\mathrm{e}}$ \\
\hline OAMa & $0.31 \pm 0.01^{b}$ & $48.11 \pm 1.03^{b}$ & $0.28 \pm 0.03^{a}$ & $95.01 \pm 1.05^{b}$ \\
\hline CAMe & $0.37 \pm 0.01^{\mathrm{a}}$ & $21.78 \pm 1.04^{\mathrm{d}}$ & $0.27 \pm 0.02^{\mathrm{a}}$ & $56.28 \pm 1.01^{\mathrm{c}}$ \\
\hline OAMe & $0.26 \pm 0.02^{c}$ & $76.87 \pm 1.04^{\mathrm{a}}$ & $0.21 \pm 0.03^{b}$ & $160.23 \pm 1.07^{a}$ \\
\hline
\end{tabular}

Control: muffin with wheat flour and sugar, CAMa: muffin with camote, achira, mashua flours and sugar, OAMa: muffin with oca, achira, mashua flours and sugar, CAMe: muffin with camote, achira, mashua flours and sucralose, OAMe: muffin with oca, achira, mashua flours and sucralose). Different letters (a,b,c,d) in the same column indicate significant differences between samples $(p \leq 0.05)$.

\subsection{Microbiological Analysis}

Microbiological counts were initially low, as expected in a heat-treated product. Then, counts of viable mesophilic aerobes showed an increased growth in the Control and in muffins formulated with sugar (CAMa and OAMa). However, counts in CAMe and OAMe remained constant until day 3; from that point onwards, exponential growth began, as in the rest of the batches containing ancestral crop flours (Figure 6A) $(p<0.05)$. Control muffins presented a slower growth after 3 days of storage, and these muffins registered $3 \log$ units less than muffins from Andean crops at the end of the study. The exponential growth shown by some muffins at the beginning may be due to the activity of some bacteria in the presence of the ingredients and to heat-treatment resistance, surviving as well to aerobic and anaerobic packaging conditions [70]. On the other hand, this fact would not explain why the counts of the control batch were lower after 6 days. Perhaps it could be attributed to the fact that flours from Andean crops may have a different type of microbiota associated with the manual preparation of the flours, as opposed to commercial wheat flour. The log phase growth after 3 days of muffins with sucralose could be attributed to this mentioned compound that somehow prevents bacterial growth for a certain time. Molds and yeasts were not detected until day 3 of storage (Figure 6B); from this day all muffins resumed growth, reaching counts $>3 \log \mathrm{cfu} / \mathrm{g}$ in all batches with the exception of OAMe, with counts below the detection limit during the whole storage period. In this connection, OAMe muffins lost the most moisture during baking (Table 2). A high moisture content in muffins will shorten the shelf-life, thus promoting microbial growth [14]. Microbial counts found in ACF muffins could be attributed to the amount of starch present in camote and oca flour, which could be a source of food for microorganisms [71], as well as the moisture of muffins and the high aw (Table 1). Mashua, in addition to its high content of vitamin C and other antioxidants [72], possesses glucosinolates, a bioactive compound that, per se or in its hydrolysis products (mostly isothiocyanates), possesses antibacterial, antifungal, nematicide and anticarcinogenic activities, among others [73]. In the present work, the possible antimicrobial effect was mainly observed in relation to this group of molds and yeasts. On the other hand, Hathorn, et al. [74], mentioned that mold and yeast counts increase according to the concentration of starch in each flour. In all muffins, there was an absence of Enterobacteria and Staphylococcus aureus initially and during storage. 

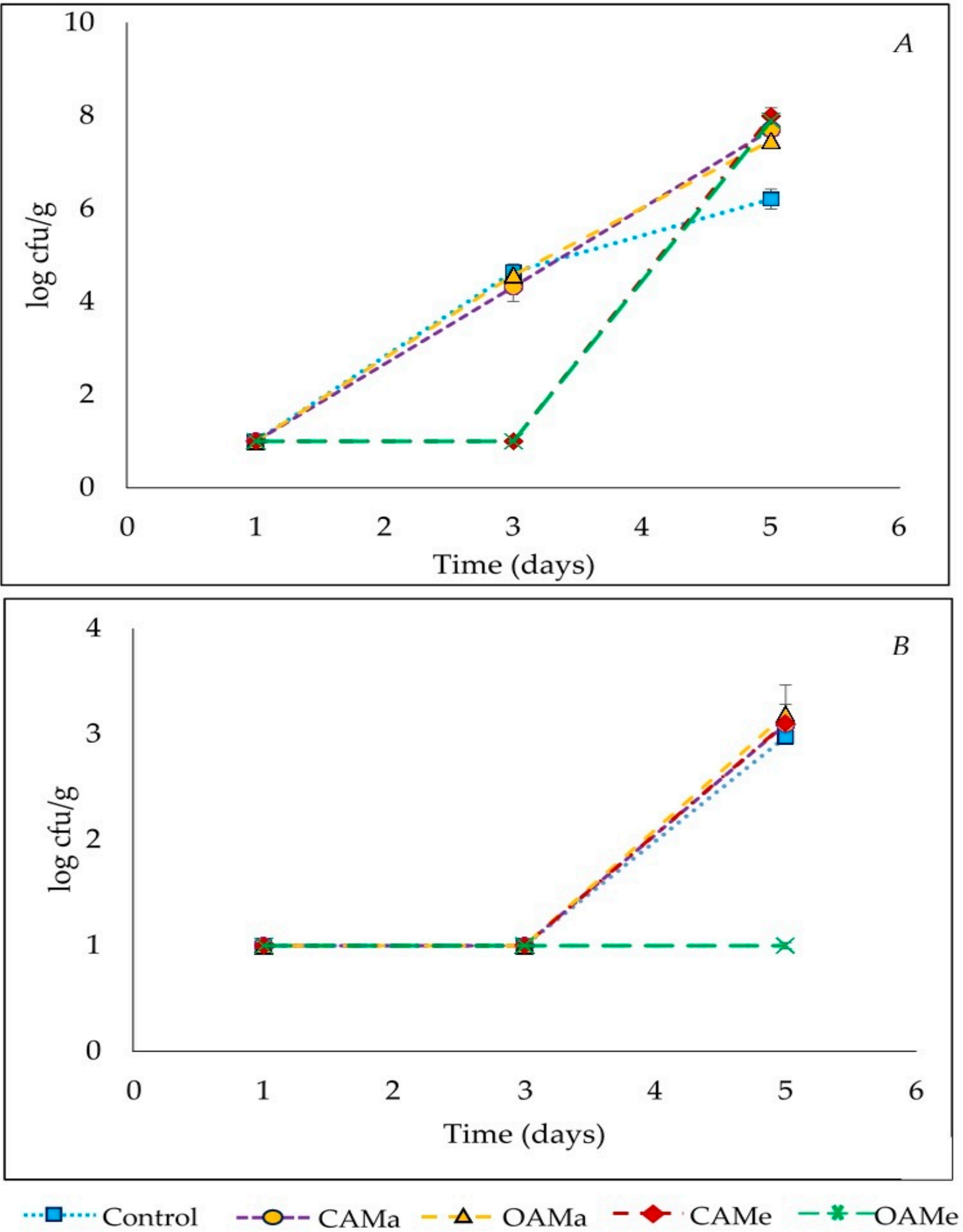

Figure 6. (A) Total aerobic mesophiles bacteria [cfu/g] and (B) mold and yeast [cfu/g]. Results are the mean \pm standard deviation. Different letters $(a, b, c)$ in the same line indicate significant differences among days for each sample $(p<0.05)$. 


\subsection{Sensory Analysis}

Sensory evaluation is fundamental in the development of new products with different and/or unexplored raw materials. In the present work, the appearance of ACF muffins was well accepted by the panelists, as it reminded them of dark chocolate or cocoa muffins and/or bakery products made from wholegrain flours, and therefore, of healthier products for conscious eating young and adult populations. Color was not included as an evaluation parameter because muffins showed large differences among them and because these products can be found in a variety of colors. In addition, no changes were registered in the sensorial evaluation for any attribute after 5 days of storage (Figure 7) in spite of the appreciable changes observed by objective textural analyses. This fact could be explained by the similar evolution of all muffins and because although the analytical method (highly sensitive) appreciates modifications, they are not enough to be perceived as undesirable changes by the judges. In this connection, Ramcharitar, et al. [75] showed that the inclusion of ground flaxseed in muffins lowered the score of consumers for all sensory attributes, with overall acceptability being rated as "neither liked nor disliked" to "liked slightly". These authors indicate the importance of prior nutritional knowledge and its influence on consumer evaluation, as the fact of consuming a healthy product can be evaluated positively or negatively depending on the age and type of consumer. In the present work, muffins with ACF and sucralose obtained the highest score, even higher than the Control muffins (Figure 7). Likewise, scores were also higher in ACF muffins were sucralose in parameters such as taste and texture $(p>0.05)$. The smell was the attribute with the lowest scores in all muffins, mainly due to the fact that they were not very aromatic, however, no unusual or strange odors or flavors were found in any case. Volatile compounds such as acids, alcohols, aldehydes, esters, ketones, pyrroles and pyrazines, and furans, hydrocarbons and lactones are involved in the aroma of wheat bread and wheat-rye, compounds that are not present in gluten-free bread [3]. These authors reported that the main differences between gluten and gluten-free bread reside in the volatile compounds in the crust due to a lack of pyrazines in the latter, and that the addition of proline and glucose (as aroma precursors in the Maillard reaction) in the pre-baked dough greatly improves the aroma of gluten-free bread. On the other hand, muffins containing sugar presented a lower acceptance; panelists described them as slightly tasteless, and the lowest score was for muffins formulated with camote, achira, mashua and sugar (CAMa).

As mentioned before, the best scored muffins were those containing sweetener in the formulation (Figure 7). Sugar substitution in the wheat muffin formulation has been previously described. So, muffins in which sucrose was partially replaced with up to 50\% stevianna obtained similar sensory and textural properties than the control muffins $(100 \%$ sucrose), but when the sugar replacement was total (100\% stevianna), negative sensory aspects were observed (bitter aftertaste, poor appearance, hard texture, and dry mouth feel) and therefore the acceptability of muffins was reduced [6]. Johnson, et al. [76], reported that yellow cupcakes formulated with a partial or combined replacement of sugar with sucralose and stevia, do not differ significantly with the control $(p>0.05)$. 


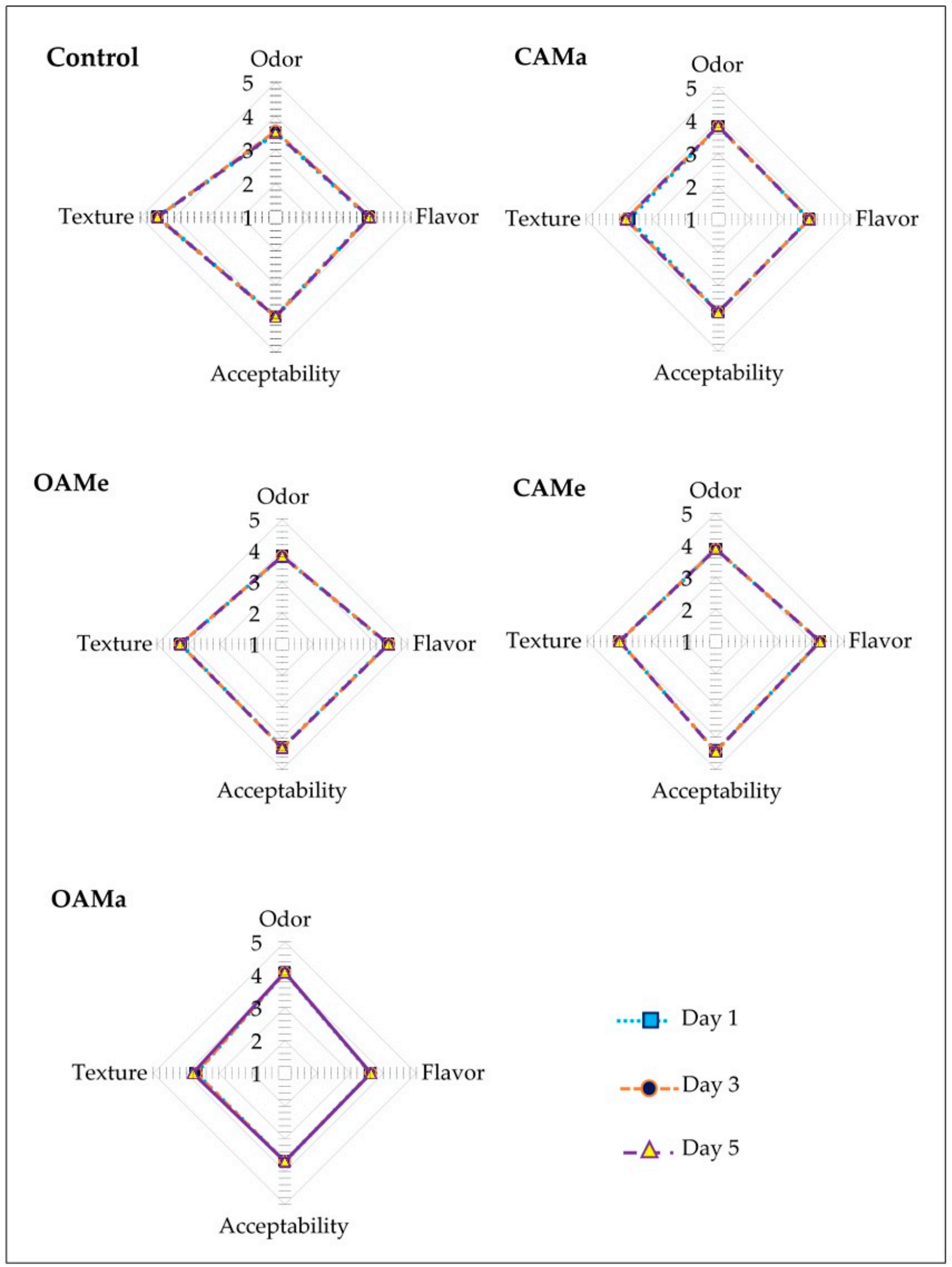

Figure 7. Sensorial evaluation of gluten-free muffins produced with ACF. 
The acceptability of gluten-free products obviously depends mainly on the incorporated ingredients and their concentration, so it is generally necessary to test different mixtures and proportions before finding a technologically viable product that is accepted by the panelists. Thus, the incorporation of other Andean crops in gluten-free bread with $25 \%$ quinoa flour obtained the highest score in flavor, and overall liking, while the control (made with buckwheat and rice flours and potato starch, without quinoa) received the lowest score [61]. In this connection, the hedonic score for texture decreased with the increase of quinoa percentage in the formulation of muffins composed of wheat, rice and quinoa [18]. Palacio, et al. [13], reported that the muffins prepared with squash seed flour (especially at $20 \%$ ) had the higher value scores with a higher overall acceptability when compared with the control (a ready to-bake dry chocolate gluten-free premix, without squash seed). Similarly, muffins with the highest sensory scores corresponded to the one containing $6 \%$ black carrot pomace and $0.5 \mathrm{~g}$ xanthana gum [31]. The good overall acceptability found in the present work is very important since fiber concentrations above $3 \%$ in the formulation are often detrimental to sensory properties [77], and in these muffins, the fiber content was much higher (Table 1). So, for all of the above mentioned, ACF is then a valuable alternative to develop muffins with high sensory acceptance.

\section{Conclusions}

Andean crop flours (ACF), as substitutes for wheat flour, are a good base to develop gluten-free muffins. ACF muffins had interesting nutritional properties, in terms of higher fiber contents, protein and reduced-fat contents when compared with wheat muffins, even in terms of nutritional claims regarding saturated fats in CAMa and CAMe $(<3 \%$ of unsaturated lipids). The texture analyses showed that muffins with ACF presented the highest values for hardness and chewiness, while cohesiveness and springiness were lower in the Andean formulas. ACF muffins showed a brownish color quite different to the blond color of their wheat flour counterpart and had a good acceptability by panelists, even better than that of wheat muffins. Thus, from a technological point of view, it has been possible to produce a gluten-free bakery product labelled as "High in dietary fiber", "Low in saturated fat" with a good sensory properties and suitable for people with special requirements.

Author Contributions: Conceptualization, D.S. and M.A.; methodology, D.S.; software, D.S. and M.A.; formal analysis, D.S., M.A., M.E.L.-C. and M.P.M.; investigation, D.S., D.R.S. and M.A.; resources, D.S., M.A., M.E.L.-C. and M.P.M.; data curation, D.S., M.A., M.E.L.-C. and M.P.M.; writingoriginal draft preparation, D.S.; writing—review and editing, M.A., M.E.L.-C. and M.P.M.; visualization, D.S., M.E.L.-C. and M.P.M.; supervision, M.A., M.E.L.-C. and M.P.M.; project administration, M.A. M.E.L.-C. and M.P.M.; funding acquisition, M.A., M.E.L.-C. and M.P.M. All authors have read and agreed to the published version of the manuscript.

Funding: This research was funded by Dirección de Investigación y Desarrollo (DIDE) and the Universidad Técnica de Ambato-Ecuador project PFCIAL-031-DS, the Inédita Project 20190015 funded by Secretaría Nacional de Educación Superior, Ciencia y Tecnología- Ecuador (SENESCYT), and The State Research Agency (AEI) from Spain and European Regional Development Fund (FEDER), through project NANOALIVAL AGL2017-84161 and by CSIC through project 202070E218.

Acknowledgments: The authors are grateful to Dirección de Investigación y Desarrollo (DIDE) and the Universidad Técnica de Ambato-Ecuador for financial support provided through the project approval by resolution 0193-CU-P-2018, PROJECT PFCIAL-031-DS “Development of a prototype of a gluten-free farinaceous mixture for pastry, using underused traditional Andean crops", the Inédita Project 20190015 "Development of wheat and gluten-free food products from underused Andean crops and agro-industrial waste", funded Secretaría Nacional de Educación Superior, Ciencia y Tecnología-Ecuador (SENESCYT), and The State Re-search Agency (AEI) from Spain and European Regional Development Fund (FEDER), through project NANOALIVAL AGL2017-84161 and by CSIC through project 202070E218.

Conflicts of Interest: The authors declare no conflict of interest. 


\section{References}

1. Singh, P.; Arora, A.; Strand, T.A.; Leffler, D.A.; Catassi, C.; Green, P.H.; Kelly, C.P.; Ahuja, V.; Makharia, G.K. Global prevalence of celiac disease: Systematic review and meta-analysis. Clin. Gastroenterol. Hepatol. 2018, 16, 823-836.e2. [CrossRef] [PubMed]

2. Khalifa, I.; Barakat, H.; El-Mansy, H.; Soliman, S. Physico-chemical, organolyptical and microbiological characteristics of substituted cupcake by potato processing residues. Food Nutr. Sci. 2015, 6, 83. [CrossRef]

3. Pacyński, M.; Wojtasiak, R.Z.; Mildner-Szkudlarz, S. Improving the aroma of gluten-free bread. LWT 2015, 63, 706-713. [CrossRef]

4. Melini, F.; Melini, V.; Luziatelli, F.; Ruzzi, M. Current and Forward-Looking Approaches to Technological and Nutritional Improvements of Gluten-Free Bread with Legume Flours: A Critical Review. Compr. Rev. Food Sci. Food Saf. 2017, 16, 1101-1122. [CrossRef]

5. Deptford, A.; Baldi, G.; Bose, I.; Badham, J.; Knight, F.; Klemm, J.; de Pee, S. Essential nutrient requirements not met by diets high in staple foods. Crisis Oppor. Double Burd. 2018, 1, 40-48.

6. Gao, J.; Brennan, M.A.; Mason, S.L.; Brennan, C.S. Effects of sugar substitution with "stevianna" on the sensory characteristics of muffins. J. Food Qual. 2017, 2017, 1-11. [CrossRef]

7. Karaoglu, M.M. Part-Baked Products. In Minimally Processed Foods: Technologies for Safety, Quality, and Convenience; Siddiqui, M.W., Rahman, M.S., Eds.; Springer International Publishing: Berlin/Heidelberg, Germany, 2015; pp. 151-172.

8. Miñarro, B.; Albanell, E.; Aguilar, N.; Guamis, B.; Capellas, M. Effect of legume flours on baking characteristics of gluten-free bread. J. Cereal Sci. 2012, 56, 476-481. [CrossRef]

9. Shevkani, K.; Singh, N. Influence of kidney bean, field pea and amaranth protein isolates on the characteristics of starch-based gluten-free muffins. Int. J. Food Sci. 2014, 49, 2237-2244. [CrossRef]

10. Pellegrini, N.; Agostoni, C. Nutritional aspects of gluten-free products. J. Sci. Food Agric. 2015, 95, 2380-2385. [CrossRef]

11. Caio, G.; Volta, U.; Sapone, A.; Leffler, D.A.; De Giorgio, R.; Catassi, C.; Fasano, A. Celiac disease: A comprehensive current review. BMC Med. 2019, 17, 1-20. [CrossRef]

12. Capriles, V.D.; dos Santos, F.G.; Arêas, J.A.G. Gluten-free breadmaking: Improving nutritional and bioactive compounds. J. Cereal Sci. 2016, 67, 83-91. [CrossRef]

13. Palacio, M.I.; Etcheverría, A.I.; Manrique, G.D. Development of gluten-free muffins utilizing squash seed dietary fiber. J. Food Sci. Technol. 2018, 55, 2955-2962. [CrossRef]

14. Man, S.; Păucean, A.; Muste, S.; Pop, A. Studies on the formulation and quality characteristics of gluten free muffins. J. Agroaliment. Process. Technol. 2014, 20, 122-127.

15. Singh, J.P.; Kaur, A.; Singh, N. Development of eggless gluten-free rice muffins utilizing black carrot dietary fibre concentrate and xanthan gum. J. Food Sci. Technol. 2016, 53, 1269-1278. [CrossRef] [PubMed]

16. Shevkani, K.; Kaur, A.; Kumar, S.; Singh, N. Cowpea protein isolates: Functional properties and application in gluten-free rice muffins. LWT 2015, 63, 927-933. [CrossRef]

17. Herranz, B.; Canet, W.; Jiménez, M.J.; Fuentes, R.; Alvarez, M.D. Characterisation of chickpea flour-based gluten-free batters and muffins with added biopolymers: Rheological, physical and sensory properties. Int. J. Food Sci. 2016, 51, 1087-1098. [CrossRef]

18. Bhaduri, S. A comprehensive study on physical properties of two gluten-free flour fortified muffins. Int. J. Food Process. Technol. 2013, 4, 251-254. [CrossRef]

19. Fuentes, C.; Perez-Rea, D.; Bergenståhl, B.; Carballo, S.; Sjöö, M.; Nilsson, L. Physicochemical and structural properties of starch from five Andean crops grown in Bolivia. Int. J. Biol. Macromol. 2019, 125, 829-838. [CrossRef]

20. Leidi, E.O.; Altamirano, A.M.; Mercado, G.; Rodriguez, J.P.; Ramos, A.; Alandia, G.; Sørensen, M.; Jacobsen, S.-E. Andean roots and tubers crops as sources of functional foods. J. Funct. Foods 2018, 51, 86-93. [CrossRef]

21. Skarbø, K. Multiple trends in interspecific crop diversity: A longitudinal case study from the Ecuadorian Andes. Genet. Resour. Crop Evol. 2016, 63, 1319-1343. [CrossRef]

22. Montúfar, R.; Ayala, M. Perceptions of agrodiversity and seed-saving practices in the northern Andes of Ecuador. J. Ethnobiol. Ethnomed. 2019, 15, 35. [CrossRef]

23. Choquechambi, L.A.; Callisaya, I.R.; Ramos, A.; Bosque, H.; Mújica, A.; Jacobsen, S.-E.; Sørensen, M.; Leidi, E.O. Assessing the Nutritional Value of Root and Tuber Crops from Bolivia and Peru. Foods 2019, 8, 526. [CrossRef]

24. Decheco, A. Componentes bioactivos funcionales en raíces y tubérculos andinos. Univ. Nac. Del Callao 2013, 1, 1-17.

25. Pacheco, M.T.; Escribano-Bailón, M.T.; Moreno, F.J.; Villamiel, M.; Dueñas, M. Determination by HPLC-DAD-ESI/MSn of phenolic compounds in Andean tubers grown in Ecuador. J. Food Compos. Anal. 2019, 84, 103258. [CrossRef]

26. Apaza Ticona, L.N.; Tena Pérez, V.; Bermejo Benito, P. Local/traditional uses, secondary metabolites and biological activities of Mashua (Tropaeolum tuberosum Ruíz \& Pavón). J. Ethnopharmacol. 2020, 247, 112152.

27. Fonseca-Florido, H.A.; Gómez-Aldapa, C.A.; Velazquez, G.; Hernández-Hernández, E.; Mata-Padilla, J.M.; Solís-Rosales, S.G.; Méndez-Montealvo, G. Gelling of amaranth and achira starch blends in excess and limited water. LWT Food Sci. Technol. 2017, 81, 265-273. [CrossRef]

28. AOAC. Official Methods of Analysis 18th Edition; The Association of Official Analytical Chemists: Washington, DC, USA, 2005.

29. AOAC. Official Methods of Analysis 16th Edition. Total Dietary in Foods-Enzymatic Gravimetric Method. In Method 985.29; AOAC, Ed.; The Association of Official Analytical Chemists: Gaithersburg, MD, USA, 1997; Volume 16.

30. Francis, F.J.; Clydesdale, F.M. Food Colorimetry: Theory and Applications; AVI Publishing Co. Inc.: Westport, CT, USA, 1975. 
31. Singh, J.; Kaur, A.; Shevkani, K.; Singh, N. Influence of jambolan (Syzygium cumini) and xanthan gum incorporation on the physicochemical, antioxidant and sensory properties of gluten-free eggless rice muffins. Int. J. Food Sci. 2015, 50, 1190-1197. [CrossRef]

32. Belorio, M.; Gómez, M. Gluten-free muffins versus gluten containing muffins: Ingredients and nutritional differences. Trends Food Sci. Technol. 2020, 102, 249-253. [CrossRef]

33. Zambrano, F.; Hikage, A.; Ormenese, R.; Montenegro, f.; Rauen, A.M. Efeito das gomas guar e xantana em bolos como substitutos de gordura. Braz. J. Food Technol. 2005, 8, 63-71.

34. Aina, A.J.; Falade, K.O.; Akingbala, J.O.; Titus, P. Physicochemical properties of twenty-one Caribbean sweet potato cultivars. Int. J. Food Sci. 2009, 44, 1696-1704. [CrossRef]

35. Ohizua, E.R.; Adeola, A.A.; Idowu, M.A.; Sobukola, O.P.; Afolabi, T.A.; Ishola, R.O.; Ayansina, S.O.; Oyekale, T.O.; Falomo, A. Nutrient composition, functional, and pasting properties of unripe cooking banana, pigeon pea, and sweetpotato flour blends. Food Sci. Nutr. 2017, 5, 750-762. [CrossRef]

36. Cui, R.; Zhu, F. Physicochemical and functional properties of sweetpotato flour. J. Sci. Food Agric. 2019, 99, 4624-4634. [CrossRef]

37. WHO. Diet, Nutrition and the Prevention of Chronic Diseases. In Technical Report Series 916; World Health Organization, Ed.; World Health Organization: Geneva, Switzerland, 2003.

38. EC. Regulation (Ec) No 1924/2006 of of 20 December 2006 on Nutrition and Health Claims Made on Foods. In 1924/2006, edited by The European Parlament and of the Council. Official Journal of the European Union; The European Parlament and of the Council: Luxembourg, 2007.

39. Bovell-Benjamin, A.C. Sweet potato: A review of its past, present, and future role in human nutrition. Adv. Food Nutr. Res. 2007, 52, 1-59. [PubMed]

40. Padmaja, G. Uses and nutritional data of sweetpotato. In The sweetpotato; Springer: Berlin/Heidelberg, Germany, 2009; pp. 189-234.

41. Villacres, E.; Pomboza, P.; Valle, M.; Lalaleo, L.; Vargas, H. The effect of sunlight on the content of thiocyanates, sugars and starches in accessions of tropaeolum tuberosum ruíz \& pavón. Ital. J. Food Sci. 2018, 30, 126-135.

42. Chisamore, A.E. Functionality of Sucralose/Maltodextrin: Isomalt Blends in Yellow Shortened Cupcakes over a 4-Day Storage Period. Master's Thesis, The University of Georgia, Athens, Greece, 2010.

43. Sarmiento, F.E. Transformación del Cupapé Usando Técnicas de Conservación. Ph.D. Thesis, Facultad de Ciencias de la Nutrición y Alimentos-Licenciatura en Gastronomía, Chiapas, Mexico, 2018.

44. Pomeranz, Y. Functional Properties of Food Components; Academic Press: San Diego, CA, USA, 2012.

45. Goswami, D.; Gupta, R.; Mridula, D.; Sharma, M.; Tyagi, S. Barnyard millet based muffins: Physical, textural and sensory properties. LWT 2015, 64, 374-380. [CrossRef]

46. Zahn, S.; Pepke, F.; Rohm, H. Effect of inulin as a fat replacer on texture and sensory properties of muffins. Int. J. Food Sci. 2010, 45, 2531-2537. [CrossRef]

47. Lancetti, R.; Palavecino, P.M.; Bustos, M.C.; León, A.E. Yacon (Smallanthus sonchifolius) flour obtention: Effect of process conditions on quality attributes and its incorporation in gluten-free muffins. LWT 2020, 125, 109217. [CrossRef]

48. Clarke, C.; Schober, T.; Angst, E.; Arendt, E. Use of response surface methodology to investigate the effects of processing conditions on sourdough wheat bread quality. Eur. Food Res. Technol. 2003, 217, 23-33.

49. Walker, R.; Tseng, A.; Cavender, G.; Ross, A.; Zhao, Y. Physicochemical, nutritional, and sensory qualities of wine grape pomace fortified baked goods. J. Food Sci. 2014, 79, S1811-S1822. [CrossRef]

50. Gómez, M.; S Sciarini, L. Gluten-free bakery products and pasta. OmniaScience Monogr. 2015, 1, 565-604.

51. Chirinos, R.; Campos, D.; Warnier, M.; Pedreschi, R.; Rees, J.-F.; Larondelle, Y. Antioxidant properties of mashua (Tropaeolum tuberosum) phenolic extracts against oxidative damage using biological in vitro assays. Food Chem. 2008, 111, 98-105. [CrossRef]

52. Baixauli, R.; Sanz, T.; Salvador, A.; Fiszman, S. Muffins with resistant starch: Baking performance in relation to the rheological properties of the batter. J. Cereal Sci. 2008, 47, 502-509. [CrossRef]

53. Ziobro, R.; Juszczak, L.; Witczak, M.; Korus, J. Non-gluten proteins as structure forming agents in gluten free bread. J. Food Sci. Technol. 2016, 53, 571-580. [CrossRef] [PubMed]

54. Baixauli, R.; Salvador, A.; Fiszman, S.M. Textural and colour changes during storage and sensory shelf life of muffins containing resistant starch. Eur. Food Res. Technol. 2008, 226, 523-530. [CrossRef]

55. Rodríguez-García, J.; Puig, A.; Salvador, A.; Hernando, I. Optimization of a Sponge Cake Formulation with Inulin as Fat Replacer: Structure, Physicochemical, and Sensory Properties. J. Food Sci. 2012, 77, C189-C197. [CrossRef] [PubMed]

56. Arora, A.; Camire, M.E. Performance of potato peels in muffins and cookies. Food Res. Int. 1994, 27, 15-22. [CrossRef]

57. Soto-Maldonado, C.; Concha-Olmos, J.; Zúñiga-Hansen, M.E. The effect of enzymatically treated ripe banana flour on the sensory quality and glycemic response of banana-wheat flour composite muffins. J. Food Sci. Technol. 2020, 57, 3621-3627. [CrossRef]

58. Rahman, A.N.F.; Bilang, M.; Ikawati, L.N. Physical and Proximate Analysis of Green Banana Cake Premix Flour. In Proceedings of the IOP Conference Series: Earth and Environmental Science, Makassar, Indonesia, 2 September 2020; Volume 486, p. 012051.

59. Campbell, A.M. Flour Mixtures, and Cereal Products in Food Theory and Applications; Macmillan Publishing Company: New York, NY, USA, 1970.

60. Andrade-Mahecha, M.M.; Tapia-Blácido, D.R.; Menegalli, F.C. Physical-chemical, thermal, and functional properties of achira (Canna indica L.) flour and starch from different geographical origin. Starch Stärke 2012, 64, 348-358. [CrossRef] 
61. Turkut, G.M.; Cakmak, H.; Kumcuoglu, S.; Tavman, S. Effect of quinoa flour on gluten-free bread batter rheology and bread quality. J. Cereal Sci. 2016, 69, 174-181. [CrossRef]

62. Solarte-Montúfar, J.G.; Díaz-Murangal, A.E.; Osorio-Mora, O.; Mejía-España, D.F. Propiedades Reológicas y Funcionales del Almidón. Procedente de Tres Variedades de Papa Criolla. Inf. Tecnol. 2019, 30, 35-44. [CrossRef]

63. Cauvain, S.P. Breadmaking: Improving Quality; Elsevier: Amsterdam, The Netherlands, 2012.

64. Agrahar-Murugkar, D.; Zaidi, A.; Dwivedi, S. Development of gluten free eggless cake using gluten free composite flours made from sprouted and malted ingredients and its physical, nutritional, textural, rheological and sensory properties evaluation. $J$. Food Sci. Technol. 2018, 55, 2621-2630. [CrossRef] [PubMed]

65. Rosalina, I.; Bhattacharya, M. Dynamic rheological measurements and analysis of starch gels. Carbohydr. Polym. 2002, 48, 191-202. [CrossRef]

66. Zaidel, D.A.; Chin, N.; Yusof, Y. A review on rheological properties and measurements of Dough and gluten. J. Appl. Sci. 2010, $10,2478-2490$.

67. Lorenzo, G.; Zaritzky, N.; Califano, A. Optimization of non-fermented gluten-free dough composition based on rheological behavior for industrial production of "empanadas" and pie-crusts. J. Cereal. Sci. 2008, 48, 224-231. [CrossRef]

68. Abdel-Shafi, M.; Wei-ning, H.; Zhen-ni, L.; Chung, O.K. Effects of acrylamide inhibition by asparagynase and sugar substitution on cookie dough rheology and baking attributes. Food Sci. 2011, 32, 157-167.

69. Ng, S.H.; Woi, P.M.; Basri, M.; Ismail, Z. Characterization of structural stability of palm oil esters-based nanocosmeceuticals loaded with tocotrienol. J. Nanobiotechnol. 2013, 11, 1-7.

70. Miñarro, B.; Normahomed, I.; Guamis, B.; Capellas, M. Influence of unicellular protein on gluten-free bread characteristics. Eur. Food Res. Technol. 2010, 231, 171-179. [CrossRef]

71. Wang, J.; Rosell, C.M.; de Barber, C.B. Effect of the addition of different fibres on wheat dough performance and bread quality. Food Chem. 2002, 79, 221-226. [CrossRef]

72. Grau, A.; Dueñas, R.; Cabrera, C.; Hermann, M. Mashua (Tropaeolum tuberosum Ruíz \& Pav.). Promoting the conservation and use of underutilized and neglected crops. 25. International Potato Center, Lima, Peru/International Plant Genetic Resources Institute, Rome, Italy. IPGRI Dei Tre. Denari. 2003, 472, 6-65.

73. Traka, M.; Mithen, R. Glucosinolates, isothiocyanates and human health. Phytochem. Rev. 2009, 8, 269-282. [CrossRef]

74. Hathorn, C.; Biswas, M.; Gichuhi, P.; Bovell-Benjamin, A. Comparison of chemical, physical, micro-structural, and microbial properties of breads supplemented with sweetpotato flour and high-gluten dough enhancers. LWT 2008, 41, 803-815. [CrossRef]

75. Ramcharitar, A.; Badrie, N.; Mattfeldt-Beman, M.; Matsuo, H.; Ridley, C. Consumer acceptability of muffins with flaxseed (Linum usitatissimum). J. Food Sci. 2005, 70, s504-s507. [CrossRef]

76. Johnson, H.; Swanson, R.; Savage, E. Descriptive sensory analysis of yellow cupcakes prepared with nutritive and high intensity sweeteners. J. Am. Diet. Assoc. 2005, 105, 48. [CrossRef]

77. Sabanis, D.; Lebesi, D.; Tzia, C. Effect of dietary fibre enrichment on selected properties of gluten-free bread. LWT 2009, 42, 1380-1389. [CrossRef] 